$\xi_{\mathrm{P}}$

\title{
Reinventing a Folk Hero in Yashar Kemal's Epic Novel, Memed, My Hawk
}

\author{
Saman HASHEMIPOUR \\ Assistant Professor at the Department of English Language and Literature, \\ Girne American University, North Cyprus
}

*Corresponding author E-mail:smnpour@gmail.com

\begin{abstract}
A millennium after the Day of Ashura, Yashar Kemal's folk hero, Memed, rises against another atrocious dynastic ruler. Husayn Ibn Ali, the grandson of Muhammad, the prophet of Islam, was killed and beheaded in the Battle of Karbala in 680 AD to end a caliphate, taking full account of claiming his life. Annually, Shiite and Alevi Muslims hold funeral ceremonies worldwide for his martyrdom on certain days to remember their liberty, as Memed's compatriots, the villagers of Değirmenoluk in Yashar Kemal's epic masterpiece, Memed, My Hawk do. Heroes do not accept injustice, but right all wrongs at all costs. Die or live as a hero, people compose ballads of protagonist's heroism and consider their liberators as holy figures.
\end{abstract}

Keywords-Yashar Kemal, Memed, My Hawk, Ashura, Folk Heroes.

\section{Introduction}

Uprising about 1550 years after the Day of Ashura, a day of great sorrow of Husayn's martyrdom at the tragic events of Karbala, Memed, Yashar Kemal's folk hero, is against another atrocious dynastic ruler. Husayn Ibn Ali, the heir of the first Islamic Rashidun Caliph and the grandson of the prophet Muhammad, was killed and beheaded in the Battle of Karbala in 680 to end the Yazidian kingdom, despite his awareness that it would cost him his life. Annually, Muslims hold funeral ceremonies for his martyrdom on certain days to remember their liberty, just as Memed's compatriots, the villagers of Değirmenoluk do. Husayn and Memed right all wrongs. They cannot live while accepting injustice. They have all the specifications of a favorite vulgar hero, so the people make ballads about their heroism and consider them as holy figures. Talat S. Halman in A Millennium of Turkish Literature: A Concise History describes this genre of literature and Yashar Kemal's relation with its vital elements:

Dealing with the merciless reality of poverty, village literature portrays the peasant threatened by natural disaster and man's inhumanity. The drama is enacted in terms of economic and psychological deprivation, blood feuds, stagnation and starvation, droughts, the tyranny of the gendarmes and petty officials, and exploitation at the hands of landowners and politicos. The lithe style records local dialects with an almost flawless accuracy. A pessimistic tone pervades much of village literature: its delineations are bleak even when occasional flashes of humor or a glimmer of hope or descriptions of nature's beauty

appear. A great strength of the genre is its freedom from the rhetoric that mars much of the poetry of social protest. When presenting deprived men and women pitted against hostile forces, the best practitioners offered an affirmation of the human spirit. Their works are often testaments to the dauntless determination of the peasant to survive and to resist-- sometimes through rebellion-- the forces of oppression. [11,120]

Memed, My Hawk is variously categorized in different genres. It is a historical novel because it describes the first years of Atatürk's Republic. One can even classify Memed, My Hawk as a political novel because, at the time of the 1960s and 1970s, when the left was in power, a movement that was began by Mustafa Kemal Atatürk, grew in Anatolia and Eastern Turkey against feudalism. It was one of Atatürk's uncompleted projects to modernize Turkey. Memed, My Hawk shows this movement in a rural Anatolia. Ahmet Oktay in What Happened to Our Novel? emphasizes "the novelist cannot separate himself from social problems, even if he wanted to." $\mathrm{He}$ continues "this is an issue not of influence but cognizance." $\mathrm{He}$ continues "the novelist's choice to interpret his own time or to reinterpret the past is a reflected choice since his objective is to investigate and reveal the inner dynamic of an age." [6] 
Memed, My Hawk is an epic novel, because it is full of heroic elements, and as a result, they compare Yashar Kemal with Spartacus, Robin Hood, Köroğlu and other folk heroes. Die or live as a hero, people compose ballads of protagonist's heroism and consider their liberators as holy figures. Besides, it can be categorized as an aesthetic novel because the novel is written artistically and Kemal made a great effort to add sense and make the reader think. The original narration way makes this novel an aesthetic story. It possesses all elements of a bestseller novel.

In the introduction of Memed, My Hawk, Yashar Kemal wrote "by creating myths, by conjuring up worlds of dreams, one can withstand the great suffering of the world and attain love, friendship, beauty, and even, perhaps, immortality" [11, xi]. Kemal says "myths" are not about heroes: "I have never believed in heroes. Even in those novels in which I focus on revolt I have tried to highlight the fact that those we call heroes are in effect instruments wielded by people" [11, x]. Azade Seyhan in Tales of Crossed Destinies: The Modern Turkish Novel in a Comparative Context wrote:

...the truth of a work of art is not necessarily in the artist's intent, it is fair to assume that the major focus of Memed, My Hawk is not the character Memed -whether immortal hero or accidental survivor- but a social imaginary that taps into a mythopoeic reserve to communicate the hope of freedom to the downtrodden. Folk heroes, idols, saviors all belong to the authors who create them, to the people who will them to life. [10,97]

Apart from Kemal's mystic and religious theme in Memed, My Hawk, there are many similarities between his protagonist, Memed, and legendary Husayn, a descendant of Mohammad, the holy prophet of Islam. Kemal's relish immensely passages are doubtful because colored descriptions of Memed's heroic perform is bringing men from the darkness of ignorance to the light of freedom. It makes us remind the inseparable accompaniments of a religious novel, which under the pretense of attacking vice, its writers contrive to minister in a vicious frankest way of teaching goodness. Consider that the history is full of saint heroes who fought against cruel dynasties. Abdi Agha, the ruthless owner, is one of these possessors who categorize all folk heroes as an anarchist. When he talks about Memed, says: "What is this amnesty? If a brigand's a brigand, his place is on the mountain" $[11,362]$. The common factor of all anarchists who became heroes is that all of them, like Memed, are victorious at the end of the story, but in against, the great hero of Islam, Husayn, is victorious through his martyrdom.

\section{Değirmenoluk Recalls Karbala}

In the Islamic calendar, the 10th day of the month of Muharram is the day of Ashura for Muslims. It is the day on which, in the year of 680 , in a place called Karbala in Iraq, Husayn, the grandson of the Prophet of Islam, Muhammad, sacrificed his life and the lives of many of his friends and family members, including his infant son Ali Asghar, in order to save Muslims from utter distortion and destruction. Later, when the Prophet of Islam passed away, Muawiya claimed himself as the ruler of Syria. Within half a century after the Prophet's passing away, a lot of water flowed beneath the bridge of Islam, but that people who knew the wrongs of Yazid, son of Muawiya, however, still accepted him as an inheritor of the Prophet and a real leader of Muslims. With the advent of Yazid, the mission of destroying the roots of Islam had succeeded. Right and wrong were so intermixed that it became impossible for an ordinary man to differentiate between them. Husayn gathered exalted family members and hand-picked friends and companions in Karbala, where many of whom had been the companions of his grandfather, the Prophet, and his father, Ali, the first Islamic Rashidun Caliph, and his brother, Hassan. Husayn had virtually gathered the moral strength of Islam to himself. With this strength, he could fight back Yazid.

Muawiyah, the Caliph, who was the son of an enemy of the Prophet Muhammed, had fought with Husayn's father, Ali, during his time and after his death. Muawiyah began fighting Hassan and poisoned him in 669. After Hassan's death, he named his son, Yazid, as successor. Later, Husayn left Medina with his sisters, daughters, sons, brothers, and the sons of Hassan. He took a side road to Mecca, but opposed Yazid and declared Yazid's attempts to establish an unlawful ruler. On the second day after the battle of Karbala, the forces of Yazid raised the head of Husayn on a lance. Yazid celebrated the occasion with great resplendence and showed by displaying the head of Husayn in his crowded and decorated court.

During the golden era of the Fatimid Caliphate, on the day of Ashura, every year the people of many Islamic countries from far and near used to gather and offer sacrifices of camels, cows, and goats, declaim elegies and curse Yazid and other murderers of Husayn. Muslims cry to reach Husayn, eagerly: "We wish we were with you!" They declare the tradition narration, "Every day is Ashura and every land is Karbala!" to live their lives as Husayn died on Ashura with the complete sacrifice for others. Likewise, at the end of Memed, My Hawk, the villagers hold a ceremony that resembles the spectacle being held every year in Iran, India, Pakistan, Lebanon, Syria, Turkey, and other Muslim countries. In Memed, My Hawk, "the inhabitants of the five villages of Dikenli gathered together. The young girls wore their best dresses. The old women donned kerchiefs white as snow." [11, 370] At Ashura annual ceremonies people wear black clothes, gather in a place and make quiet services like the inhabitants of Dikenli: "The drums were beating" $[11,370]$. Muslims keep mourning by poems about the day of Ashura that recites by drums and other instruments. Like the Dikenli inhabitants, who hold the ceremony "each year...for three days and three nights," [11, 370] Muslims hold their ceremony for a few days of the anniversary. Numerous poems are composed eulogizing one of the greatest epics of heroism in the history of humankind, and this is one of them:

Had Ashura Day only known

What calamity in it went on!

Its aura would not have dawned,

Its light would not have shown,

Its sun would not have been bright(er),

Its grief stole from the days their light.

And so every month, and so every day

O, Allah! What a momentous day.... [2]

Comparing Yashar Kemal's protagonist with the Muslim heroes is not a sensible comparison, but universal literary figures are the best conduct of religious saints by showing their domination of even literary figures. For example, after a millennium, Husayn Ibn Ali remains a revolutionary figure against all tyrants and oppressors. He will continue as a symbol of dignity and freedom for Muslims. It is a shred of evidence that Husayn cannot be considered as merely a reckless rebel risking his own and his family's lives for his ambition. He refused to break his oath of allegiance to Muawiyah and his son, Yazid. Like his father, he was firmly convinced that his family was divinely chosen to lead the community.

Although Memed puts his family's life in danger to rescue his countrymen, as Husayn's tragedy features other attributes of a real epic hero. Robert Durey Osborn (1835-1889), the Major of the Bengal Staff Corps, writes, Husayn "had a child named Abdallah, only a year old. He had accompanied his father on this terrible march. Touched by its cries, he took the infant in his arms and wept. 
At that instant, a shaft from the hostile ranks pierced the child's ear, and it expired in his father's arms. Hosain placed the little corpse upon the ground. 'We come from God, and we return to Him!' he cried; 'O Lord, give me strength to bear these misfortunes!'” [4]

Husayn is remembered as a symbol of freedom and self-possession against tyranny and slavery. He never bowed to tyranny and the oppressive regime of Yazid. He said that a dignified death is better than a humiliating life. Yazid used to despise people oppress them, but Husayn by his real personality and death defeated the tyrant. His revolt was the spark for the end of the Umayyad dynasty. Even, the dead Husayn was more dangerous to Yazid than the live Husayn. His martyrdom in Karbala remains a symbol of freedom, dignity, and rejection of tyranny. Thus, unlike any other city, Karbala, a city in Central Iraq, in Western Asia, which is bordered by Turkey, has its name engraved in the memory of generations and throughout the Muslim world. Believers remember Karbala with sorrow and distress, for they remember the history of the master of all martyrs, Husayn, like the role of Değirmenoluk in Memed, My Hawk.

Shiism believes Yazid has all the characteristics of being an "infidel," the word Memed uses against anyone who is considered wicked. Formally, it means a person who is against the Muslim faith or people. The night before the war, Husayn gathered his family and followers and told them that the foe wants him. He said them you are free to go while it is dark, but all of them refused. On the day of Ashura, Yazid's armies attacked the women and put the tents in the fire. They have beaten the children and women with whips and ripped off their belongings. Husayn and his followers at Karbala profoundly influenced the tide of time in various ways, in the fields of philosophy, political thought, social reform, and the cultural resurgence of the Muslim world and the oppressed of the world. He initiated a movement that has proved to be an archetype representing an eternal struggle of truth against falsehood, justice against injustice and tyranny, human dignity against dehumanization, the revolt of the oppressed against oppressors, and overpowering of the strong by society's weak. Husayn's movement, which stands unequaled in its greatness and fills pages upon pages of history, continues to be recreated as a popular platform and available weapon to repel repressive forces, imperialism, and Western domination in many parts of the developing world.

The historical progress of Islam, according to Gandhi, "is not the legacy of the Muslim sword but a result of sacrifices of Muslim saints like Husain." [7] Edward Gibbon believes the tragic scene of the death of Husayn "will awaken the sympathy of the coldest reader." [5] Besides, the great British novelist of the last era, Charles Dickens says: "If Hussain fought to quench his worldly desires, [as alleged by certain Christian critics] then I do not understand why his sisters, wives, and children accompanied him. It stands to reason therefore that he sacrificed purely for Islam" [7]. Thomas Carlyle, the Scottish historian, and essayist reminds that the lesson we get from the tragedy of Karbala is that Husayn and his companions "illustrated that the numerical superiority does not count when it comes to truth and falsehood. The victory of Husain, despite his minority, marvels me!" [9] Lal Nehru writes: "Imam Hussain's sacrifice is for all groups and communities, an example of the path of righteousness." [9] Besides, Dr. Rajendra Prasad writes, "The sacrifice of Imam Hussain is not limited to one country, or nation, but it is the hereditary state of the brotherhood of all mankind." [9]

\section{Memed Calls Popular Saints Up}

From a different religious viewpoint, there are many similarities between Memed and Imam Mahdi's ascension. Muslims believe the Mahdi was unseen from the eyes of ordinary people and nobody could see him. Muslims hope that someday their dear Mahdi will appear and lighten the eyes of those believers who are waiting for him in his illuminating face. Also at the end of Memed, My Hawk, Yashar Kemal uses this element to his protagonist: "No news of Slim Memed was ever heard again. No sign or trace of him was ever found" $[11,370]$. Even we can find other related similarities between this novel and other innocent Shiite holly figures, but Husayn's view about community problems and their attempts to enlighten the people makes us say a bird in the hand is worth two in the bush.

We even find similarities between Jesus Christ and Husayn in that both of them rejected tyranny and wrong and gave themselves for freedom, salvation, dignity, and righteousness. Their path is one, and their salvation is by following their path of peace and justice. Before them, Moses and Aaron defied the tyranny of Pharaoh and Aaron was deemed weak by his people when Moses left to receive the Ten Commandments. The sacrifice of life that is characteristic of human beings is based on faith in the truth. Within religious circles, the sacrifice of life is considered to be proper only for the sake of spiritual goals. Jesus himself is said to have shown Peter "by what kind of death he was to glorify God" (John 21:19), and he promised his disciples, "some of you will be put to death" (Luke 21:16). There was an appointed number of Christians who would be martyred, as John said in Revelation $6: 11$, “. . . until the number of their fellow servants and their brothers should be complete, who were to be killed as they had been." In Islam, Husayn's martyrdom provides evidence of the moral victory of right over wrong, of virtue over vice, of principle over compromise, of the, oppressed over the oppressor, of the, denied over the denier; the ultimate victory of blood over the sword. The sacrifice of Husayn was about standing in the face of oppression, no matter the cost, and to die with honor is rather than living in subjugation to injustice.

Husayn gave a great message of self-sacrifice to human beings who intend to live under the flag of freedom. Husayn did not fear death, and this is a characteristic of Memed. Husayn and Memed's foes hate them as they hate their fathers. Yazid and his fathers were against Husayn's father, Ali and even their grandparent, the prophet Muhammad. In Memed, My Hawk, without any clear mentioned reasons, Abdi Agha, who symbolizes tyrant rulers in this epic novel, hated Memed's father, and even villagers admit infidel Abdi Agha's sanctity: "'Yes, child. That infidel was already your father's enemy" $[11,45]$. But Husayn and Memed come to the rescue, fill the bill and get hold of the keeping people on the rails. They come to help, kick infidels in the teeth and bring home the bacon, but in different ways. Husayn gives his life and Memed goes through fire to reach his aim but loses his family like Husayn. Both of them believe that actions speak louder than words; they try hard, but obtain a nation's trust: "WWoman-hearted Memed! See all the villagers staring at you. ...Will you bring Abdi on us again?"' [11,367].

For a Muslim believer, Ashura teaches valuable life lessons which Husayn tried to show them. The battle for truth and justice is an ongoing one and must be fought daily. In Iran, Ayatollah Khomeini, the Iranian religious leader of the 1979 Islamic Revolution, recreated and revived the spirit of "Ashura" through his messages against the despotic Pahlavi rule and the exploitive domination of alien powers over the developing nations throughout the world. He enrolled the flame hidden in "Ashura" as a process in the human history of evolving a better society that could defend the principles of justice, social equity and equality, and the cultural independence of the developing world. In the Middle East and some parts of North Africa, the recent Islamic Awakening, called "Arab Spring" in countries such as Egypt, Tunisia, Yemen, and Bahrain, may be considered a replica of Husayn's revolution for freedom. Karbala at the Husayn's era symbolizes his eternal existence in the world, 
which has implications and meanings. The Ashura anniversary rituals mirror the purposes and consequences of the event and are employed to organize the feelings of the attendants by remembering a historical case of extreme injustice. It is applied against the contemporary tyranny, especially at times of political and social disorder. Ashura serves as a framework for expressing opposition against the prevailing conditions at any moment in time.

\section{Conclusion}

Yashar Kemal mixed class conflict of Marxist Socialism with his protagonist's search for identity and freedom, and to reach his aim, Kemal writes a heroic epic which involves all kinds of themes. Like Homer, Shakespeare, and Cervantes, Kemal's modern novel contains psychological features that make the reader think. Kemal's hero joins the fray and helps the peasants. Shiite writings about Karbala highlight as well the different kinds of literature influenced by the legend, and that links the history of Husayn with ideas that have for long occupied humanity such as the origin of the universe and life, in which, Husayn is eternal with the elegies and the simulation ceremonies. The style of this literature is melodramatic and stirs up sympathy for the pain of Husayn, and represents Karbala as a revolution against oppression and tyranny. This study shows how Yashar Kemal as a Muslim Anatolian writer arises under the influence of convergence Nosairians and espousers of the historical event consciously or unconsciously influenced by the Karbala tragedy in Memed, My Hawk.

\section{References}

[1] Akbayır, S. Zamansız Bir Karşılaşma: Orhan Pamuk-Yaşar Kemal. Istanbul: Ferfir Yayınları, 2011.

[2] "Ashura." Al-Islam.org, www.al-islam.org/maqtal-al-husaynabd-al-razzaq-al-muqarram/ashura.

[3] Bahmanpour, N. The Story of Ashura. Tehran: Danesh-Amooz, 2008.

[4] Durie Osborn, R. Islam Under the Arabs. Delaware Scholarly Resources, 1976. pp. 126-7.

[5] Gibbon. E. The Decline and Fall of the Roman Empire. London: Methuen \& Co,1911. volume 5, 391,2.

[6] Halman. Talat.S. A Millennium of Turkish Literature: A Concise History. New York: Syracuse University Press. 2011.

[7] "Hussein Ibn Ali." Wikipedia, Wikimedia Foundation, 6 Feb. 2018, en.wikipedia.org/wiki/Hussein_ibn_Ali.

[8] Oktay, A. Romanımıza Ne Old?. Istanbul: Dünya Kitapları. 2004.

[9] Rizvi, S. Manzoor N. Unique Sacrifice of Imam Hussain for Humanity. Message of Peace Inc. (Pyame-Aman), 2014. pp. 233, 373 and 380 .

[10] Seyhan, A. Tales of Crossed Destinies: The Modern Turkish Novel in a Comparative Context. New York: The Modern Language Association of America, 2008.

[11] Yashar K. Memed, My Hawk. New York: New York Review Books, 2005. 